\title{
Alinhavando vínculos: circulação de imagens de moda nas redes sociais
}

\author{
Autor: Lívia Laura Matté \\ Orientador: Dirce Vasconcellos Lopes
}

\begin{abstract}
Resumo: Este estudo se propõe a delinear os aspectos da moda, na contemporaneidade, sob um viés comunicacional, ou seja, é uma busca por identificar, por meio das imagens que circulam em redes sociais, as características que distinguem a moda contemporânea circunscrita à pósmodernidade. Para tanto, realizou-se uma pesquisa bibliográfica a fim de conhecer os conceitos de pós-modernidade. Entre os autores estudados, optou-se por seguir os caminhos trilhados pelo sociólogo francês, Michel Maffesoli, visto que suas ideias acerca da pós-modernidade são fundamentais para explicar a contemporaneidade e a moda na pós-modernidade. O corpus desta pesquisa consiste em imagens extraídas de uma rede social de compartilhamento de imagens de moda: Lookbook.nu: Collective Fashion Consciousness. Acredita-se que estas imagens constituem materiais carregados de informações que podem explicar a moda na pós-modernidade, além de contribuir para discussões sobre a criação de vínculos possibilitados pela circulação de tais elementos imagéticos.
\end{abstract}

Palavras-chave: Imagem (Moda). Comunicação - Aspectos sociais. Comunicação visual. Redes sociais. Comunicação e arte. 


\title{
Tacking bonds: fashion image circulation in social networks
}

\begin{abstract}
This study aims at delineating the aspects of fashion in contemporary times under a bias of communication. It is a search to identify, through the images that circulate on social networks, the characteristics that may distinguish the contemporary fashion circumscribed to the so called postmodernity. Therefore, we performed a bibliographic research in order to understand the concepts of post modernity. Among the authors studied, we chose to follow the pathways taken by the French sociologist Michel Maffesoli, since his ideas about post modernity are the key to explain the contemporary fashion in post modernity. The corpus of this study consists of images extracted from a social network of fashion image sharing: Lookbook.nu: Collective Fashion Consciousness. We believe that these images are loaded with information that might explain fashion in post modernity, and contribute to discussions about the creation of bonds enabled by the circulation of these imagery elements.
\end{abstract}

Keywords: Imaging (Fashion). Comunication. Social aspects. Visual comminication. Social networks.

Dissertação completa disponível em: http://www.bibliotecadigital.uel.br/ document/?view $=$ vtls000186483 